\title{
A Method for Environmental Data Management Applied to Megasites in the State of Sao Paulo, Brazil
}

\author{
Marcos Barbosa, Reginaldo A. Bertolo, Ricardo Hirata \\ University of Sao Paulo-USP, Instituto de Geociências, Sao Paulo, Brazil \\ Email: bertolo@usp.br
}

How to cite this paper: Barbosa, M., Bertolo, R.A. and Hirata, R. (2017) A Method for Environmental Data Management Applied to Megasites in the State of Sao Paulo, Brazil. Journal of Water Resource and Protection, 9, 322-338.

https://doi.org/10.4236/jwarp.2017.93021

Received: December 9, 2016

Accepted: February 25, 2017

Published: February 28, 2017

Copyright $\odot 2017$ by authors and Scientific Research Publishing Inc. This work is licensed under the Creative Commons Attribution International License (CC BY 4.0).

http://creativecommons.org/licenses/by/4.0/

\begin{abstract}
The management of contaminated areas with multiple sources of contamination (megasites) is among the biggest challenges for the Brazilian environmental agencies, especially because aquifers in big urban areas, like the Sao Paulo Metropolitan Region, are important sources of water for human supply purposes. One of the main reasons that hamper the proper management of urban environmental problems is a lack of a unified system where all information can be easily integrated into regional studies. To address this problem, a method for data integration and management using a Geographic Information System (GIS) was developed. This method was applied to the case of a regional contamination of an aquifer by chlorinated solvents at a former industrial district in Sao Paulo city, named Jurubatuba, but the final product might also be used for data management of contaminated areas for the entire State of Sao Paulo. The main result obtained was that the site-by-site approach for aquifer contamination management is ineffective. Furthermore, there are many other suspected and potential sources of contamination without any information available after more than 10 years since the contamination problem was discovered at the FIZ 131.
\end{abstract}

\section{Keywords}

Megasite, Chlorinated Organics, Geographic Information System

\section{Introduction}

The regional contaminations of aquifers, also known as megasites, are zones that comprehend multiple contamination sources and multiple legal responsible parties [1]. The environmental management of these areas represents a great challenge for all stakeholders involved. They are the regulatory agencies, the legal responsible 
for the contaminated land (usually the owner of the property), technicians and members of the society among others. The management process is usually marked by the lack in communication due to the existence of distinct and antagonistic interests between the parties [2].

Several cases of megasites contamination have resulted in the development of environmental management methodologies [1] [3] [4] [5] [6] [7]. These methodologies usually make use of a risk based assessment for resources allocation to mitigate the impacts to specific assets or communities to be protected. All these projects have one thing in common, the development and application of Geographic Information Systems (GIS). These are tools to support the implementation of an integrated information management strategy, such as SMARTe [8], DECERNS [9] and those developed by Ascough et al. [10] and Malczewski [11].

These methodologies of data integration using GIS applied to the management of environmental problems are still under development in Brazil, which is not a big issue when dealing with contamination liabilities at individual site scale. However, when dealing with megasites and regional contamination, it is very difficult to establish a link between concentrations of pollutants in groundwater and a given legal responsible for the source of contamination. This scenario is aggravated by the existence of commingled plumes, many times involving dense non-aqueous phase liquids (DNAPL), and complex hydrogeological scenarios, like fractured bedrock aquifers. This is the case of the Jurubatuba district, a former industrial area located in Sao Paulo city, Brazil (Figure 1). The area has presented a legacy of environmental liabilities due to intense industrial occupation in the last decades and inappropriate handling of chlorinated solvents has led to contamination of the fractured bedrock aquifer.

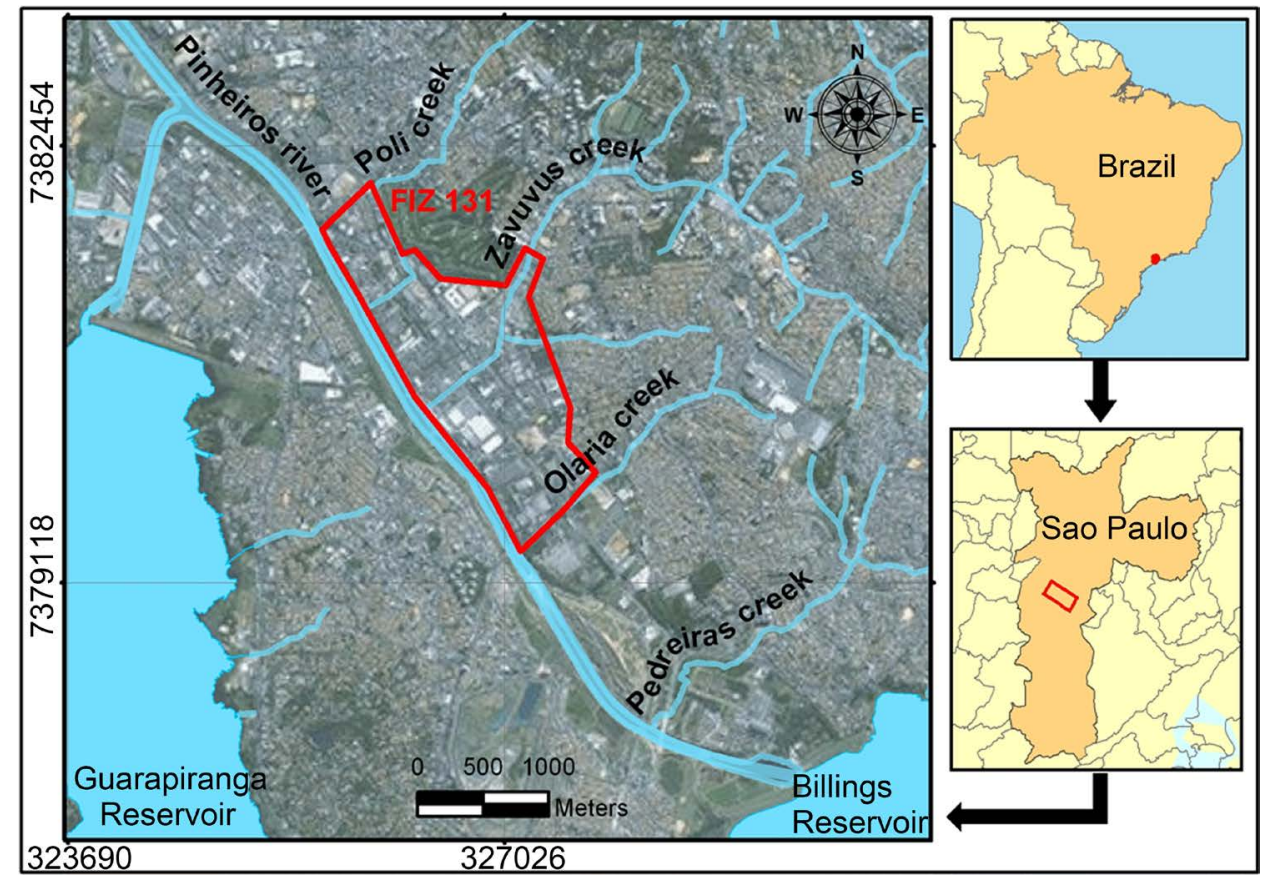

Figure 1. The study area in Sao Paulo city (FIZ 131 area), a subarea of the Jurubatuba district. 
The environmental agency of Sao Paulo state (CETESB) has an information system for potential sources of pollution which is used to register contaminated sites, but it contains only cadastral and licensing information. All the data related to environmental studies and historic evolution of the sites are stored in physical files, electronic PDF files or spreadsheets. Each of these materials is separated in individual records, making the information fragmented and inaccessible.

In order to develop the management of megasites in Sao Paulo, it is necessary to exchange the current approach being used, of managing each contaminated site (or land property) separately. Instead, in these areas of high density of potential sources of contamination, the extension of the plumes should be the focus. In this way, the whole process of denial of the impact and exemption from liability by the polluters is inhibited.

The international experience demonstrate that the creation of a GIS applied to the management of contaminated sites is fundamental to advance this process. The transition to this approach is laborious and complex, but it can be facilitated by software and tools that are already consolidated. Therefore, data can be integrated with external databases and incorporate numerical modeling of flow and transport of contaminants [2] [12].

The objective of this work was to develop a method for integration of environmental data for soil and groundwater contamination using a GIS-based system. This method was applied on a pilot scale to a subarea of the Jurubatuba case [13], the Former Industrial Zone 131 (FIZ 131). This methodology can later be applied by the environmental authorities to improve the management of all contaminated sites.

\section{Study Area}

The industrial district at the former FIZ 131 area started in the early 1950's but the development process was more intense on the 1970's. The area was occupied by medium to large industries from diverse sectors, such as chemical, metallurgic and car industries, among others [14]. In 2004, a specific municipal directive extinguished the Industrial Zones in the city of Sao Paulo that became classified as mixed use zones (residential, commercial and industrial). Since then, the FIZ 131 has undergone on an accelerated process of redevelopment. The legacy of environmental liabilities left by the industries has put human receptors at risks, as the old buildings have given rise to residential complexes, commercial offices and services. The main groups of contaminants impacting groundwater are chlorinated ethenes, ethanes and methanes, which were found in several supply wells with depths of up to $300 \mathrm{~m}$.

Historically, groundwater has been used mostly by industries in production and for sanitary purposes [13]. It is estimated that more than $70 \%$ of the supply wells operate illegally in the region and there is little or no control over their exploitation conditions [15]. Most of the wells exploit the fractured Crystalline Aquifer System, constituted by Precambrian metamorphic rocks (gneiss, schist) [16]. However, there are wells that also exploit the Sedimentary Aquifer System (Ceno- 
zoic sediments, associated to the Sao Paulo Sedimentary Basin).

The environmental agency initiated more effective actions in order to identify and control the environmental liabilities of soils and groundwater in the region in 2001. The leading edge was one of the local industries that reported the presence of high concentrations of chlorinated solvents in soil and groundwater inside their property [14]. With the identification of other sources of contamination and plumes crossing the boundaries of properties, the environmental agency began to monitor the quality of groundwater withdrawn from supply wells. The confirmation of the widespread presence of chlorinated solvents in dozens of deep supply wells came in the first regional campaign. This lead to the creation of a groundwater "Zone of Restriction of Use" instituted by a state water resources agency in 2005.

To better understand the extension of the impacts in the supply wells and the Crystalline Aquifer System, a regional study was later conducted to assess the quality of groundwater and the production capacity of the existing wells. This study comprised a review of several aspects of the Jurubatuba district with respect to potential sources of pollution, land use, geology and hydrogeology [13]. However, the data used for assessing groundwater quality was limited to few samples collected in the supply wells available. Thus, a new restriction and control zone was created which is maintained until now [17].

The current restriction zone is divided into three levels of restriction (high, medium and low), where drilling of new wells are not allowed in any of them. If the detection of chlorinated organics is confirmed in any of the operating supply wells, it should be immediately decommissioned. Wells that do not indicate the detection of these compounds should be monitored quarterly in high and medium restriction zones and semi-annually in the low restriction zones. Illegal wells must be identified to receive the concession, while decommissioning is mandatory in cases of abandoned supply wells. The restriction zone is a useful institutional measure, avoiding receptors to get in contact with contaminated groundwater. However, this measure does not have any effect on the reduction of contaminant mass in the aquifer or the sustainable use of groundwater.

Despite all the performed studies at FIZ 131 over the past 15 years, little has advanced for the solution of the regional environmental problem. This is due to environmental assessments limited to individual known source areas which rarely comprised the crystalline aquifer. So far, studies have not attempted to integrate data from different sites into a single database.

\section{Methodology}

The first step to integrate data was the selection of a Geographic Database (GDB) model, a relational database that supports geometric features and its customization. The File Geodatabase was adopted to store spatial data [18], this is a standard relational database management system for tables and attributes information. The model adopted was the Arc Hydro Groundwater data model [19], which facilitates the process of database customization. The model includes the representation of 
geological, hydrogeological, hydroestratigraphic, soil boring, wells and time series. The GDB implementation contemplated several activities which were described in Strassberg et al. [18] to develop the database structure and relationships which were modified to the FIZ 131 needs and presented in Figure 2, where feature classes and relationships that were adopted to the framework data model are presented.

Data acquisition was made through the state environmental agency (Cetesb) files, referring to the processes of contaminated sites located in the former FIZ 131 area. Data from supply wells were obtained at the state water resources agency DAEE. The data acquisition was also complemented by research on literature, such as academic papers and theses [15] [20] [21]. Raw data was preferably imported into the GDB. The reliability assessment of the data collected by fieldworkers was not part of the scope of this work.

The identification of current property owners and activities were made by door to door survey, on line research, environmental pollution registry database and reports of contaminated sites. Areas not related to the use of solvents in the past are considered of low potential of contamination. Those properties associated with the use of solvents were considered potentially contaminated. In the case of known use of solvents, the properties were considered suspected of contamination. When there were no records of previous activities, the area was classified as unknown. All known contaminated sites listed by the environmental agency were registered as contaminated.

The registration of the contaminated areas was done based on the "List of contaminated and rehabilitated areas", available at the environmental agency and referred to the year 2014 [22]. From the files, the processes to be evaluated were selected. Among the information collected, the following stand out: location of soil borings and wells, well and lithological logs, hydraulic tests, hydrogeological cross-sections, soil and water chemical analysis, soil and water physical properties.

Supply wells information was obtained from the licensing processes available in the water resources agency (DAEE), accessed in 2013. These were complemented with some of the illegal wells data available [21] and contaminated sites reports. Lithological and well construction information, location and chemical analysis

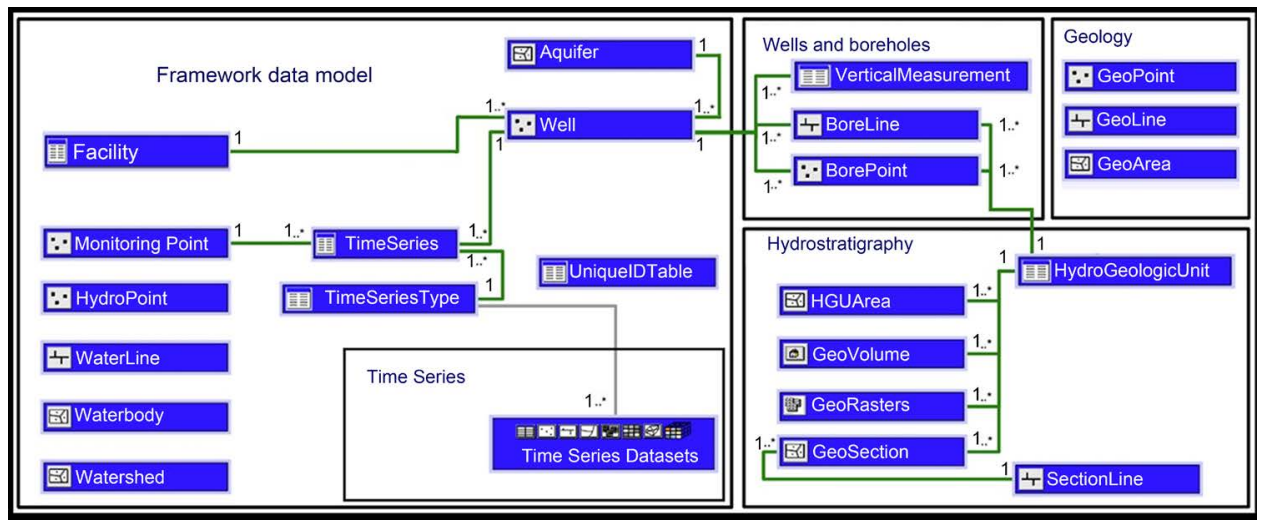

Figure 2. Geodatabase structure implemented at the FIZ 131 [19]. 
were the most important data selected.

Lithological data were found to be very heterogeneous on the way they were presented in the reports accessed. Prior to import data into the GDB, they had to be reclassified in generic groups using texture classes [23]. Four lithological groups were adopted for classification purposes, technogenic deposits, sediments (Quaternary and Tertiary origin), saprolite and hard rock. The original $\log$ description was maintained in a database field to facilitate a possible reclassification or new interpretation in cases of disagreement or doubt.

The verification and adjustment of geographic location (coordinates and elevation) was performed by a topographic survey campaign that was carried out in a series of monitoring wells located on public areas. They were used as a reference for the wells inside the contaminated sites which were not accessible. The planimetric coordinates adopted were the SIRGAS 2000 system and the orthometric elevation was obtained through the IBGE MapGeo 2010 geoidal model.

After the systematization of all the information in the database, cartographic products were prepared. The first part of this activity consisted in the spatial representation of the data, resulting in characterization maps of the physical environment. The second part consisted in the interpretation of products based on the relation of data for the management of contaminated areas (e.g. map of priority areas to be investigated).

\section{Results}

The material assessed for data integration included 220 reports of contaminated sites, 35 supply wells licensing reports, 4 academic reports as well as geographic information developed by public agencies available online (city infrastructure data, geology, hydrography, land use, groundwater restriction area, among others). The visualization of these data allowed a better analysis of the regional contamination management. Due to the high amount of data constantly generated, a working method was developed (Figure 3). This working method is presented in a flow chart format that describes the steps to acquire the relevant data, process and import them into the GDB. To date, 189 properties have been registered, 1219 wells (1011 monitoring, 109 sampling, 64 remediation and 35 supply), 10684 water level data, 93313 groundwater chemical analysis data and 175 hydraulic tests. Despite all this data, essential aspects needed for understanding the regional problem remain poorly understood.

\subsection{Properties Characterization}

From the 189 properties registered, 21 are contaminated sites, where 13 are by chlorinated solvents, 12 already used solvents and 41 had activities related to the use of solvents. Although practically all the properties have been registered in the database, almost half do not present any information about past activities. This may be an underestimate number of suspected and potentially contaminated sites. Based on the historical records of use of solvents, it was possible to indicate priority areas for investigating groundwater (Figure 4). The criterionwas based on the proximity to contaminated sites, suspected or with potential of contamination. 


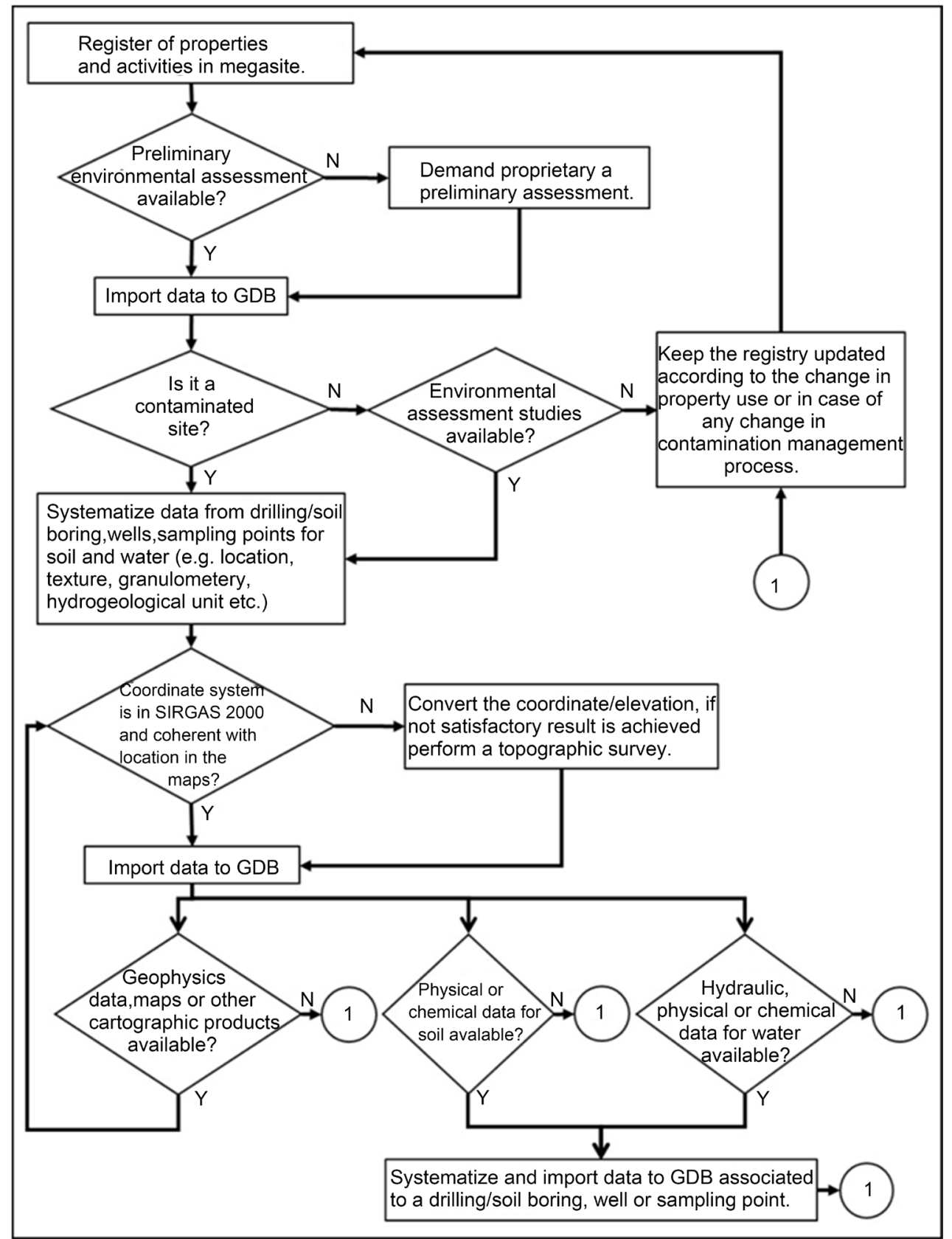

Figure 3. Data management process for importation into the GDB.

The FIZ 131 presents a total area of $2.6 \mathrm{~km}^{2}$. The priority areas for investigation comprise approximately $0.8 \mathrm{~km}^{2}$, while the properties which present some degree of environmental investigation sum an area of approximately $0.7 \mathrm{~km}^{2}$. Poor data distribution and existence of large areas without any information draws attention. Therefore, despite all the effort from the environmental agency since 2001, one third of its coverage remains unknown with regard to the existence of other sources of contamination.

\subsection{Geological and Hydrogeological Characterization}

Although there are more than a thousand lithologic logs of soil borings which 


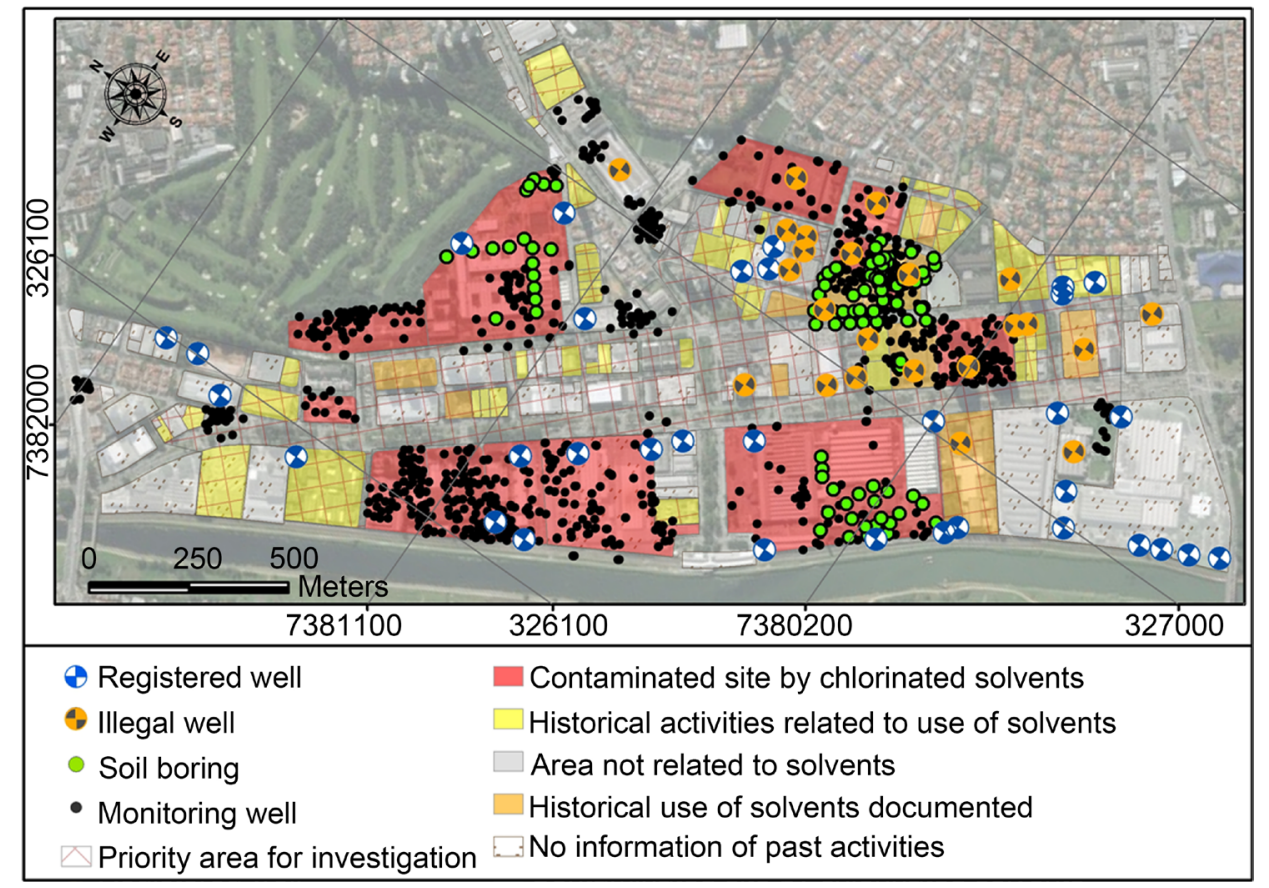

Figure 4. Priority areas for groundwater quality investigation. This figure also shows the sites, soil borings and wells that were registered into the GDB.

intercept different geological units (technogenic deposits, Quaternary alluvial deposits, paleogenic sediments of the Tertiary, saprolite and bedrock), there is no regional understanding of the lateral and vertical dimension of these units where they occur. Data interpolation from soil borings and wells, using IDW, resulted in the map of thickness of the sediments (Figure 5). The data suggest the occurrence of a structural control of the sediment thicknesses, which also explains the accentuated change in the Zavuvus creek path (Figure 1 and Figure 5) and the abrupt thickening of the sediments in the central portion of the study area.

Five geological cross-sections were prepared along the FIZ 131 to better understand the lateral and vertical extent of the lithological units (Figure 6), which is an automatic process once all data is organized in the GDB. In the example presented, the cross-sections were build crossing areas with higher amount of data, resulting in more reliable interpolation and the consolidation of aquifer geometry for hydrogeological conceptual models. Alluvial deposits and Paleogenic sediments were grouped into a single class, because in general there was no differentiation of the descriptions in the reports.

Two aquifer units occur in the area, the Sedimentary and the Crystalline [16]. The sedimentary aquifer system is an unconfined to semiconfined unit of primary porosity, which is very heterogeneous and anisotropic due to the occurrence of interbeded layers of sand and clay sediments of the Sao Paulo Basin [24]. The hydraulic conductivity data ranges from $10^{-9}$ to $10^{-3} \mathrm{~m} / \mathrm{s}$. In the FIZ 131, the distribution of hydraulic heads of the shallow aquifer indicates that the water table surface is similar to the one of the ground surface, indicating that the probable discharge zones of the shallow aquifer units are the Pinheiros river and the Poli and Zavuvus creeks (Figure 1). 


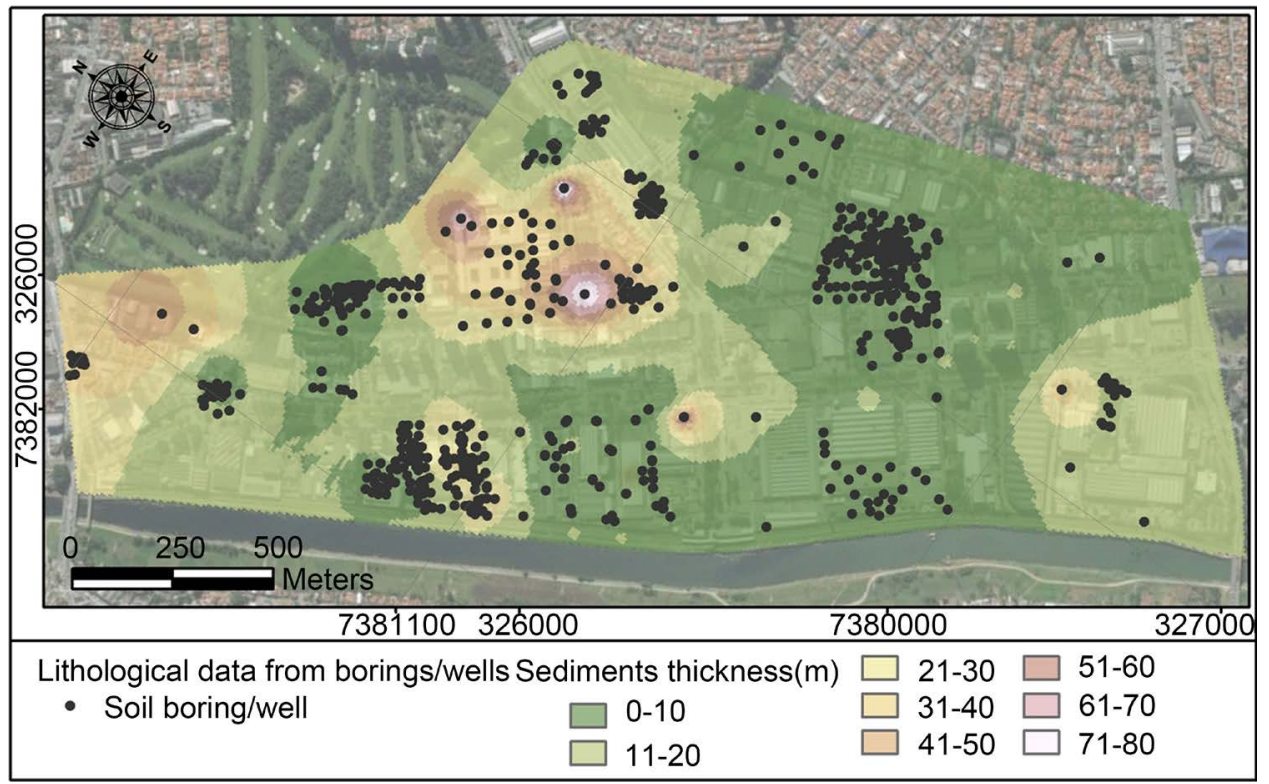

Figure 5. Sediments thicknesses at the FIZ 131 based on the soil borings and wells lithological data using the IDW interpolation method.

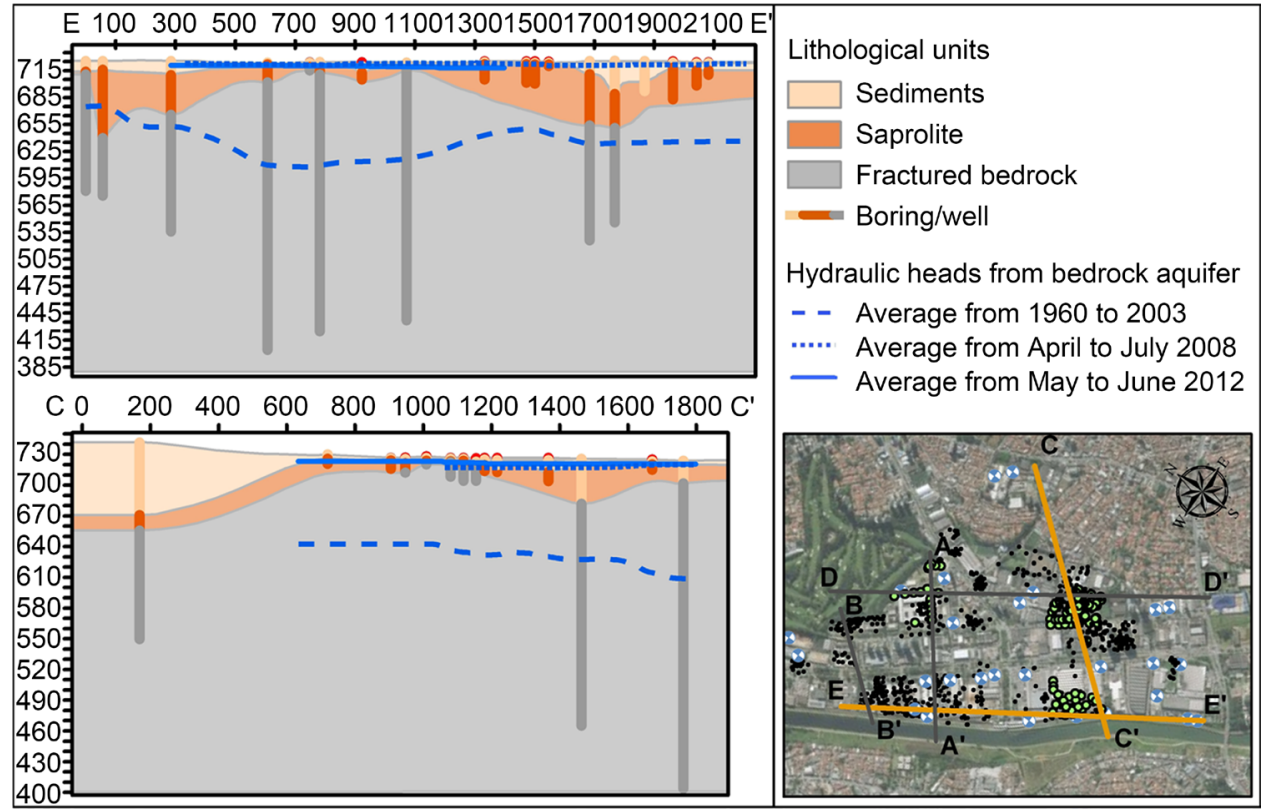

Figure 6. Cross sections $\mathrm{C}$ and $\mathrm{E}$ at the FIZ 131 based on soil borings and wells. Elevation on the $\mathrm{y}$ axis and distance in the $\mathrm{x}$ axis are expressed in meters.

The Crystalline Aquifer System is divided into two compartments with distinct behaviors, saprolite and fractured bedrock. The saprolite unit is dual porosity and very heterogeneous and anisotropic medium, where hydraulic conductivity values vary from $10^{-8}$ to $10^{-4} \mathrm{~m} / \mathrm{s}$, depending on the weathering degree of the parent rock [25]. This unit presents a lower hydraulic head relative to the upper sedimentary aquifer, indicating the existence of a vertical downward potential. Distribution of hydraulic heads indicates that discharge zones of this unit also comprise the Pinheiros River and the Poli and Zavuvus creeks. 
The bedrock aquifer is composed of migmatites, schists and gneisses. It is a fractured medium and water flows through the discontinuities of the rock. The hydraulic conductivity values in this system vary from $10^{-9}$ to $10^{-6} \mathrm{~m} / \mathrm{s}$. The activities of data acquisition resulted in the obtainment of a limited amount of information for this aquifer, which would allow the understanding of the current and past conditions of hydraulic heads of the deep fractured bedrock aquifer. However, it is known that after the interruption of the wells pumping in 2005, the hydraulic heads raised tens of meters, which resulted in an average hydraulic head of this unit close to the ones observed for the shallow sedimentary aquifer. A recent study has shown that there are two main groups of fractures with a higher probability of controlling water flow in the region: SE fractures of low dip and parallel to the rock foliation, and NW subvertical fractures [26].

\subsection{Spatial Distribution of Chlorinated Solvents in Groundwater}

In 2005, the environmental agency performed a regional groundwater sampling from dozens of supply wells (of up to 300 meters deep) and concentrations of chlorinated compounds above the potability standards were detected in most of them along the FIZ 131 area. Even after nearly ten years of this study, many areas with suspected or potential sources of contamination remain unknown, as many do not yet conducted environmental liability studies. On the other hand, in the 13 sites where the existence of source of contamination were identified, many rounds of environmental assessments were performed, although little progress was made in investigations of greater depths inside the saprolite and the deeper fractured bedrock aquifer units.

Chlorinated organics are present in the three aquifer levels at the FIZ 131, being the shallowest portion the most investigated unit and with the greatest extention of contamination. The contaminants occurring with higher frequency and intensity are the chlorinated ethene compounds, although the chlorinated methanes and ethanes are also present. The maps of chlorinated organics distribution in groundwater presented (Figure 7 to Figure 9) were drawn considering the data obtained from 2010 to 2012, which presents a good spatial coverage.

Chlorinated organics distribution on the sedimentary and saprolite aquifers indicate three major contamination focus, formed by at least two contaminated sites (Figure 7 and Figure 8). However, it is possible to notice distinct characteristics of solvents (presence of different parent and degradation products compounds) in neighboring contaminated sites. Concentration averages in the monitoring wells ranging from undetected to more than 90,000 $\mu \mathrm{g} / \mathrm{l}$ (sum of all chlorinated organics detected). Comparing the concentration maps for the sedimentary aquifer (Figure 7) and the areas with no information (Figure 4), there are too many gaps of information to delineate the impacted zone.

Almost half (56\%) of the monitoring wells presents filter and pre-filter sections longer than 2 meters, which can cause dilution of the samples. Even though chlorinated organics concentrations in the sedimentary aquifer were found to be higher than $1 \%$ of the solubility limit, in some cases concentrations of up to $10 \%$ of the 


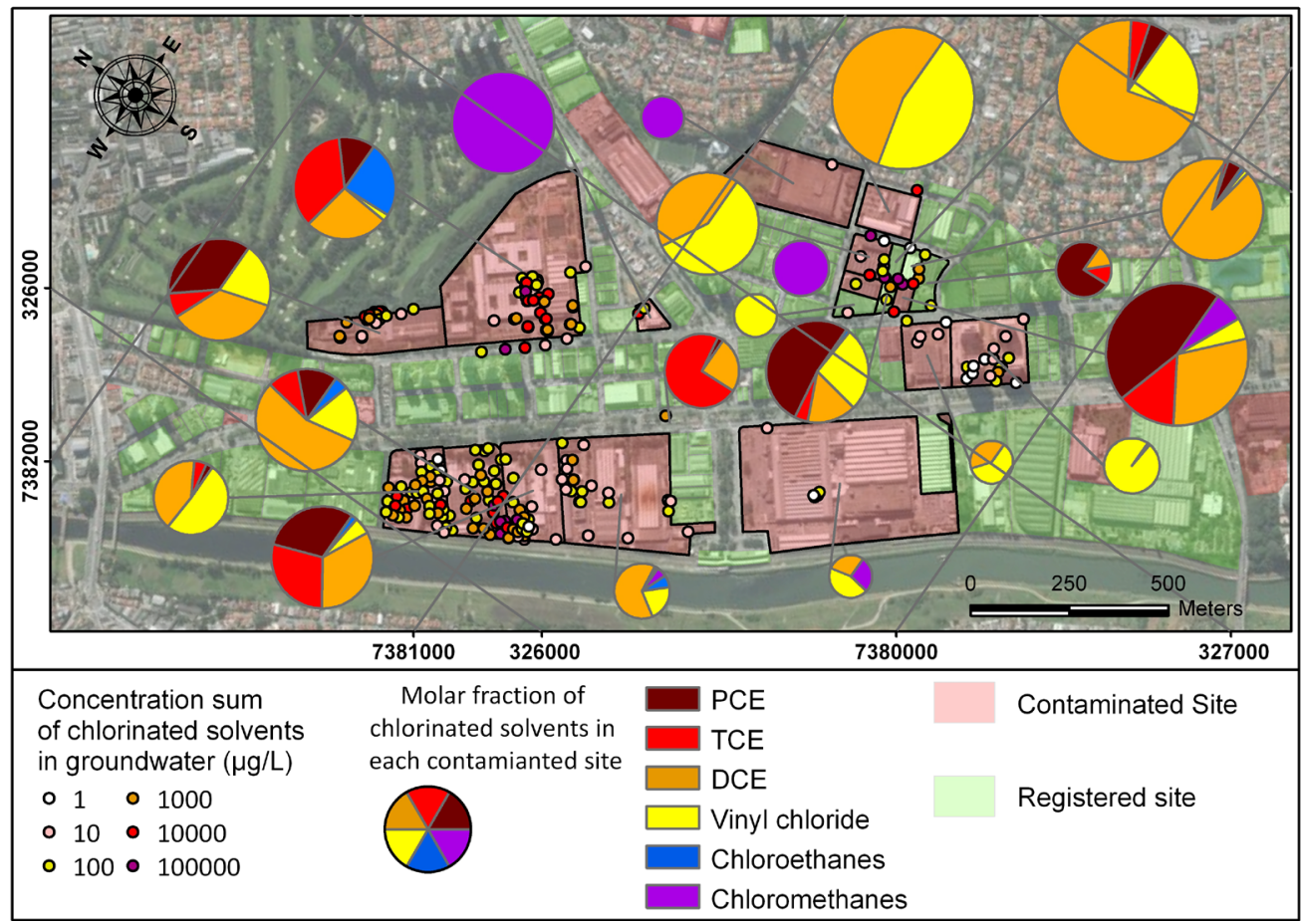

Figure 7. Chlorinated organics occurrence in the shallow sedimentary aquifer. Pie charts representing the average molar fraction of compounds per site and size associated to the log scale for the sum of total mass of solvents. Dots representing the average mass concentration of chlorinated solvents in the monitoring wells. Data available from 2010 and 2012.

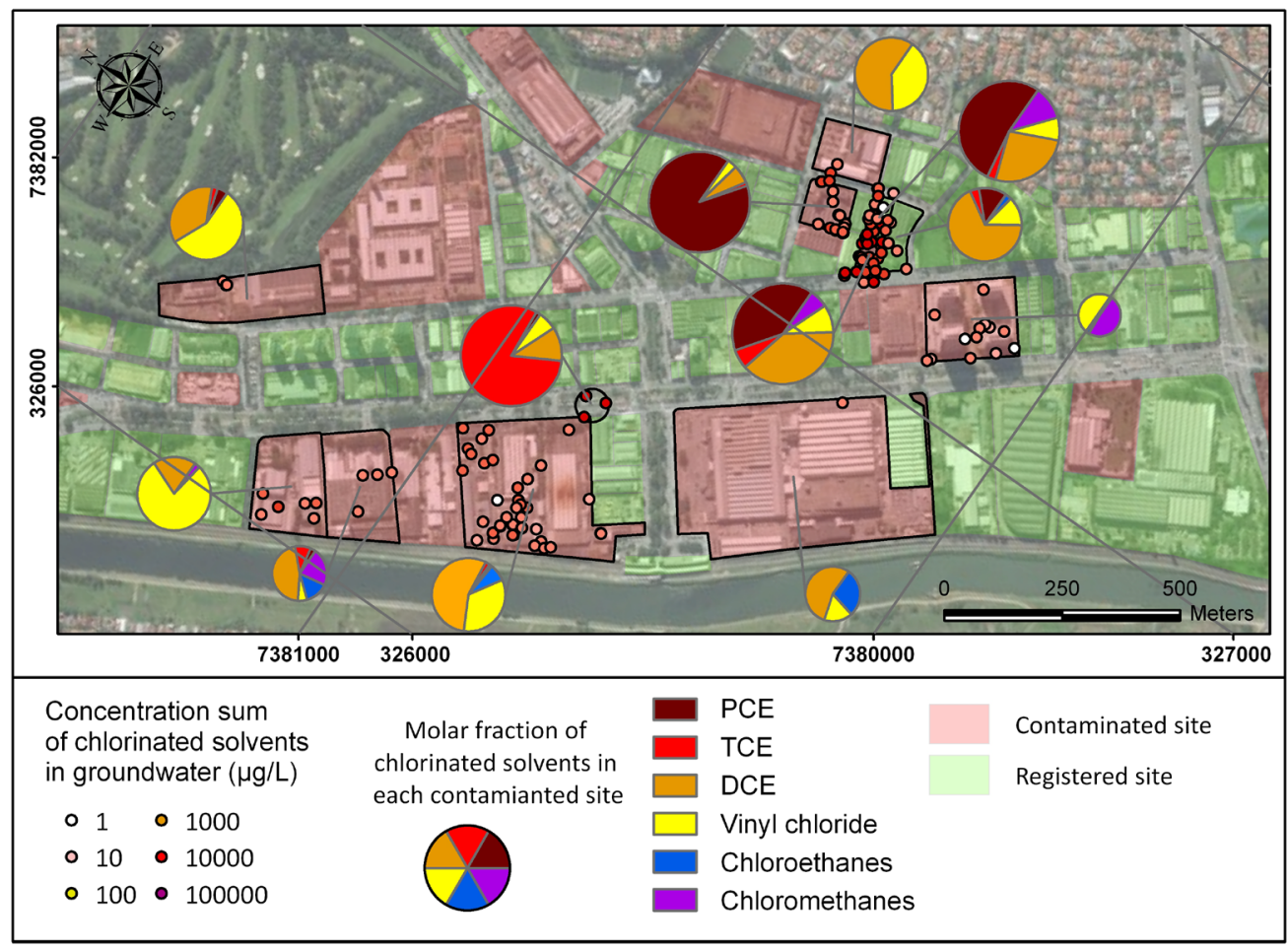

Figure 8. Chlorinated organics occurrence in the saprolite aquifer. Pie charts representing the average molar fraction of compounds per site and size associated to the log scale for the sum of total mass of solvents. Dots representing the average mass concentration of chlorinated solvents in the monitoring wells. Data available from 2010 and 2012. 
solubility limit were found. Concentrations of organic compounds greater than $1 \%$ of their effective solubility are indicative of the existence of NAPL [27]. Therefore, there is a strong evidence of active secondary sources of contamination in sites under management.

Regarding the bedrock aquifer contamination, only two groundwater sampling campaigns covering the entire network of supply wells are available. Both are campaigns carried out by the environmental agency in 2005. The time gap does not allow drawing a parallel between the current chemical data of monitoring wells and the bedrock aquifer campaign. Furthermore, sampling performed in 2005 was conducted directly at the tap of the well, which may have caused a mixture of water pumped from all the fractures and screens. Therefore, it is not possible to understand if the concentrations are related to shallower or deeper aquifer units.

The main compounds impacting the fractured bedrock aquifer also correspond to the chlorinated ethenes (Figure 9). The presence of parent compounds (PCE and TCE) varies from site to site, suggesting origins from different sources of contamination. Supply wells with higher concentrations of chlorinated organics, above $1000 \mu \mathrm{g} / \mathrm{l}$, were found close to the most impacted regions of the sedimentary aquifer. In some cases, the presence of father compounds did not match. This difference can be observed in some wells located in the southern portion of the area, where five neighboring wells present the detection of PCE concentra tions but no known source in the surrounding areas. Hence, it is not possible to stablish direct correlation between source area and concentration measured at a specific deep supply well.

One aspect to be considered in the interpretation of supply wells data is their

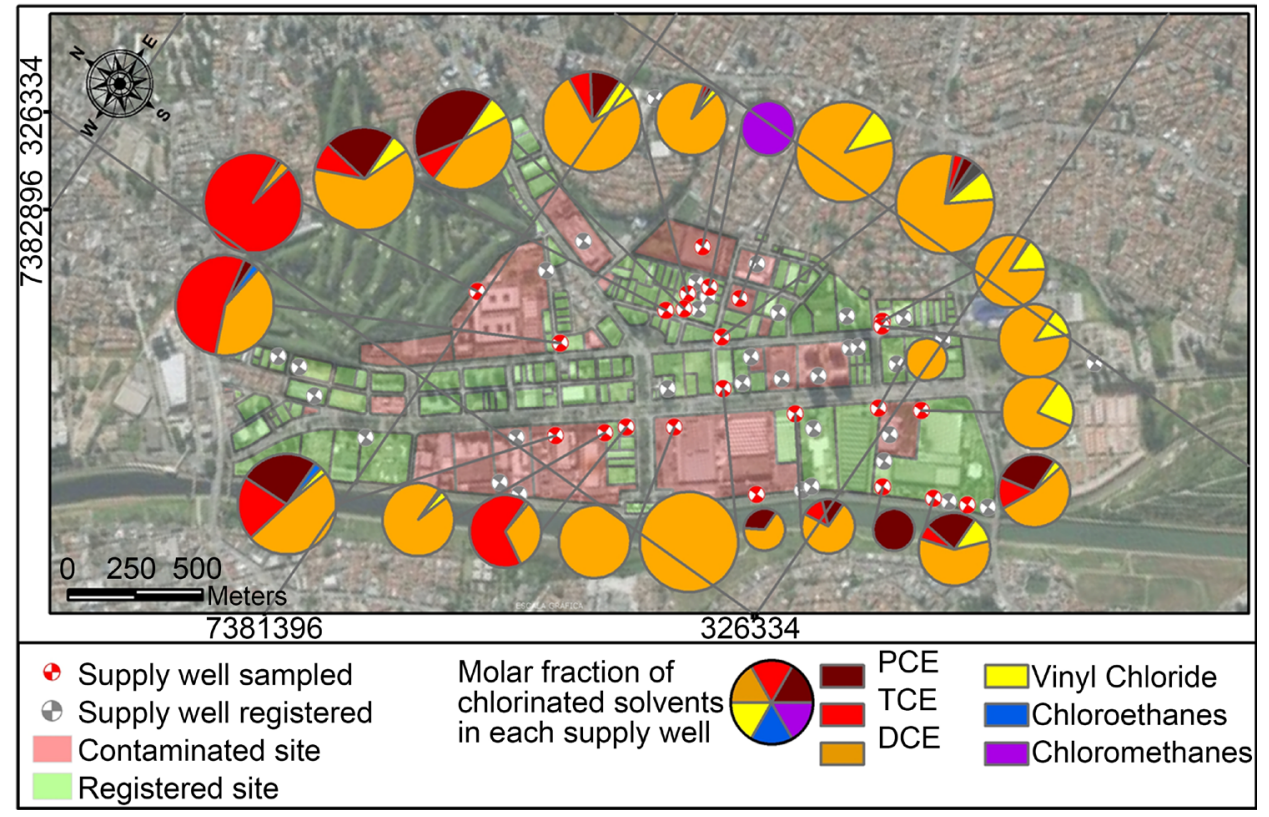

Figure 9. Chlorinated solvents presence in the supply wells in the monitoring campaign conducted by environmental agency in March 2005. Pie charts representing the molar fraction of the compounds per well and size associated to the log scale for the sum of total mass of solvents. 
influence on the transport of contaminants. One hypothesis is that the wells themselves were responsible for carrying contaminants into the bedrock aquifer [15]. On the other hand, the deepening of the contamination due to the higher density of the solvents and the existence of hydraulically active vertical fractures cannot be disregarded. Currently, the few chemical analysis data from supply wells indicate that concentrations are very low; however, this may be bias due to dilution effect. Due to the detection of these compounds in groundwater, the supply wells were abandoned, which caused the recovery of the hydraulic heads to levels similar to the ones observed in the shallow sedimentary aquifer (Figure 6).

Given the spatial distribution of the data and the existence of numerous potential areas with suspected contamination that have not been investigated, the current environmental panorama is out of date. The main problem is due to the inefficient way of managing information which impacts the progress of the site management. Site scale approach leads to the lack of organization, maldistribution and inability to correlate information, which hinders the process of megasite management.

Despite the evolution in site specific management, the extent of contamination and the best way to deal with the problem in the long term basis remains unknown. Meanwhile, the abandoned supply wells were not decommissioned and continue to be opened boreholes, which may represent a conduit that serves to transport contaminants from the shallow to the deeper aquifer units. Therefore, it is probable that contaminants are still migrating in the different aquifer units, which may increase the responsibility of the state to ensure the security of the population health. Human health risks may increase due to the consumption of groundwater from supply wells, since it is known the operation of illegal supply wells in the area of pumping restriction.

\subsection{Method for Participative Data Management}

The proposed method for data management allows the spatial visualization of essential information (Figure 10) for environmental management of megasites by regulatory agency. The biggest difficulty is the format of data available, hardcopies, PDF and spreadsheets, in some cases. The organization of the processes itself does not facilitate the integration of data. Studies are ordered by date of execution and old reports information gets lost in the pile of files. The systematization and importation of data proved to be a laborious activity, since these were found in numerous and voluminous folders (Table 1).

To deal with this challenge, a method for information management, that can be developed and applied to megasites in Sao Paulo state, was developed to faci litate processing and interpretation of the data (Figure 10). It is assumed that the environmental agency would be the administrator of the GDB system. So, it is part of their responsibilities the designing and maintenance of the GDB that will receive the data. It is also their responsibility the establishment of the format and the characteristics of the data that can enter the GDB, which allows the standardization and organization of the data. On the other hand, those responsible for the conta minated sites, as well as companies responsible for generating information (tech- 
nical managers, drilling companies, laboratories, among others) would be responsible for the data generated and inserted in the BDG.

Regulatory agencies can use the integrated database to support decisions and create policies more efficiently (Figure 11). They have direct and indirect impact in the GDB evolution. Direct by inserting data they produce into the GDB; indirect

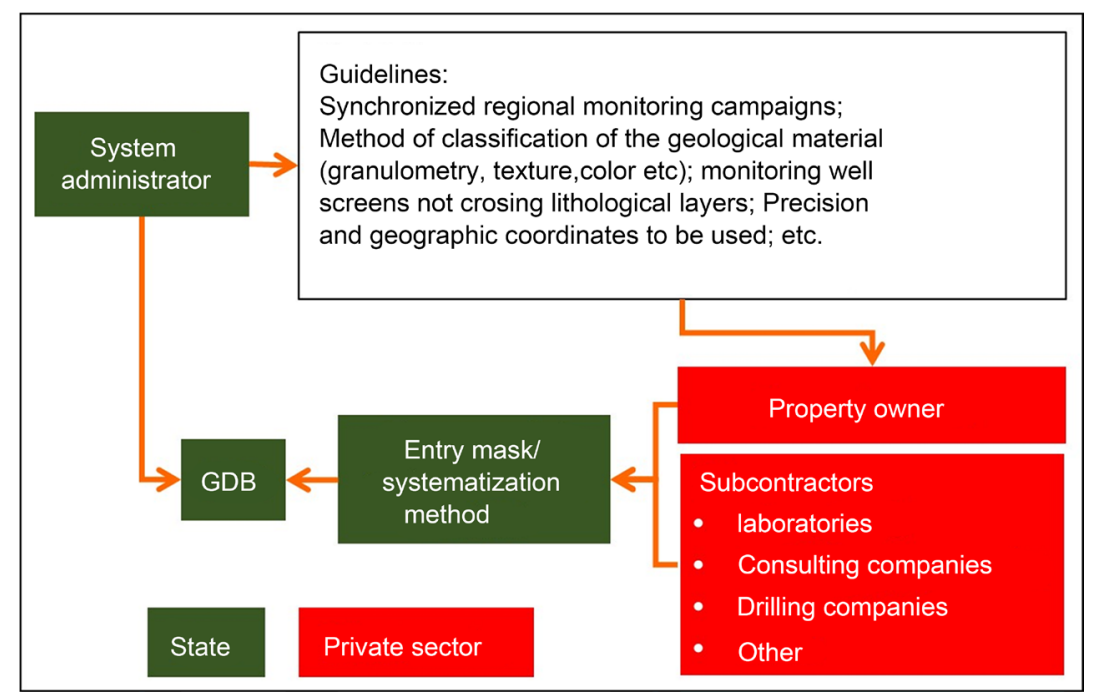

Figure 10. Proposed method for the integration of the environmental data for soil and groundwater contamination.

Table 1. Essential data to be inserted into the geodatabase organized by feature class. HGU refers to Hydrogeology Unit and COC to Compounds of Concern.

\begin{tabular}{|c|c|c|c|c|c|c|c|}
\hline $\begin{array}{l}\text { 1. Property } \\
\text { register }\end{array}$ & 2. Soil boring & $\begin{array}{c}\text { 3. Soil } \\
\text { characteristics }\end{array}$ & 5. Aquifer & 6. Well & $\begin{array}{l}\text { 7. Hydraulic } \\
\text { head }\end{array}$ & $\begin{array}{l}\text { 8. Hydraulic } \\
\text { parameters }\end{array}$ & $\begin{array}{l}\text { 9. Water } \\
\text { quality }\end{array}$ \\
\hline ID & ID & ID & ID & ID & ID & ID & ID \\
\hline address & $\begin{array}{l}\text { geographic } \\
\text { location and } \\
\text { elevation }\end{array}$ & Date & description & Date & Date & Date & Date \\
\hline $\begin{array}{l}\text { geographic } \\
\text { location }\end{array}$ & item 1 ID & collection method & $\mathrm{HGU}$ & $\begin{array}{l}\text { drill and } \\
\text { installation } \\
\text { diameter }\end{array}$ & $\begin{array}{l}\text { water level and } \\
\text { hydraulic head }\end{array}$ & type of test & $\begin{array}{l}\text { collection } \\
\text { method }\end{array}$ \\
\hline site history & depth interval & depth interval & $\begin{array}{c}\text { data } \\
\text { source }\end{array}$ & depth & $\begin{array}{l}\text { free phase } \\
\text { presence }\end{array}$ & result & parameter \\
\hline $\begin{array}{c}\text { pollutant } \\
\text { classification }\end{array}$ & lithological unit & Item $5 \mathrm{HGU}$ & coments & $\begin{array}{l}\text { screen, casing } \\
\text { and seal depth } \\
\text { interval }\end{array}$ & data source & $\begin{array}{l}\text { method of test and } \\
\text { interpretation }\end{array}$ & result \\
\hline $\begin{array}{c}\text { historical use or } \\
\text { activities related to } \\
\text { COC }\end{array}$ & $\begin{array}{c}\text { texture } \\
\text { description }\end{array}$ & $\begin{array}{l}\text { density, organic } \\
\text { matter content, } \\
\text { moisture }\end{array}$ & - & $\begin{array}{l}\text { top of casing } \\
\text { elevation }\end{array}$ & coments & data source & data source \\
\hline data source & granulometry & $\begin{array}{l}\text { grain size propor- } \\
\text { tion and others }\end{array}$ & - & well use & - & coments & coments \\
\hline coments & item $5 \mathrm{HGU}$ & $\begin{array}{l}\text { total and effective } \\
\text { porosity }\end{array}$ & - & current status & - & - & - \\
\hline - & $\begin{array}{l}\text { type (soil boring, } \\
\text { well etc.) }\end{array}$ & chemical data & - & item 5 ID & - & - & - \\
\hline- & data source & data source & - & data source & - & - & - \\
\hline- & coments & coments & - & coments & - & - & - \\
\hline
\end{tabular}


by stablishing guidelines for specific study areas and public policies regarding the environment and land use. This cyclic process can harmonize the communication between the agencies involved in the water resources management and effectiveness of their actions.

\section{Conclusions}

The proposed method based on GIS has demonstrated its usefulness for the management of megasites. Several limitations on the management of the FIZ 131 were identified in this study due to site-by-site approach used by the environmental agency: (1) contaminated sites are in different stages of investigation; (2) information is concentrated on the minority of the contaminated sites (21 sites), while most of the properties that used chlorinated solvents in the past are still not investigated (53 properties); (3) most of the available data from contaminated sites are from shallow investigations of the sedimentary aquifer, while investigations of the underneath saprolite and the fractured bedrock aquifer are exceptions; (4) groundwater campaign in restricted areas and shallow monitoring wells makes little contribu tion to the understanding of the megasite problem and is a waste of re-sources.

Overall, the adoption of this method would increase the productivity of environmental agency technicians, reduce the physical volumes of processes and increase the possibilities of managing contaminated areas in a more integrated way. Thus, many other areas like Jurubatuba may be better managed with re sources already available, benefiting not only civil society but also local economy through the increase in water supply and service. Therefore, the results will be the safeguard of the public health, the optimization of resources and the gradual improvement of groundwater quality.

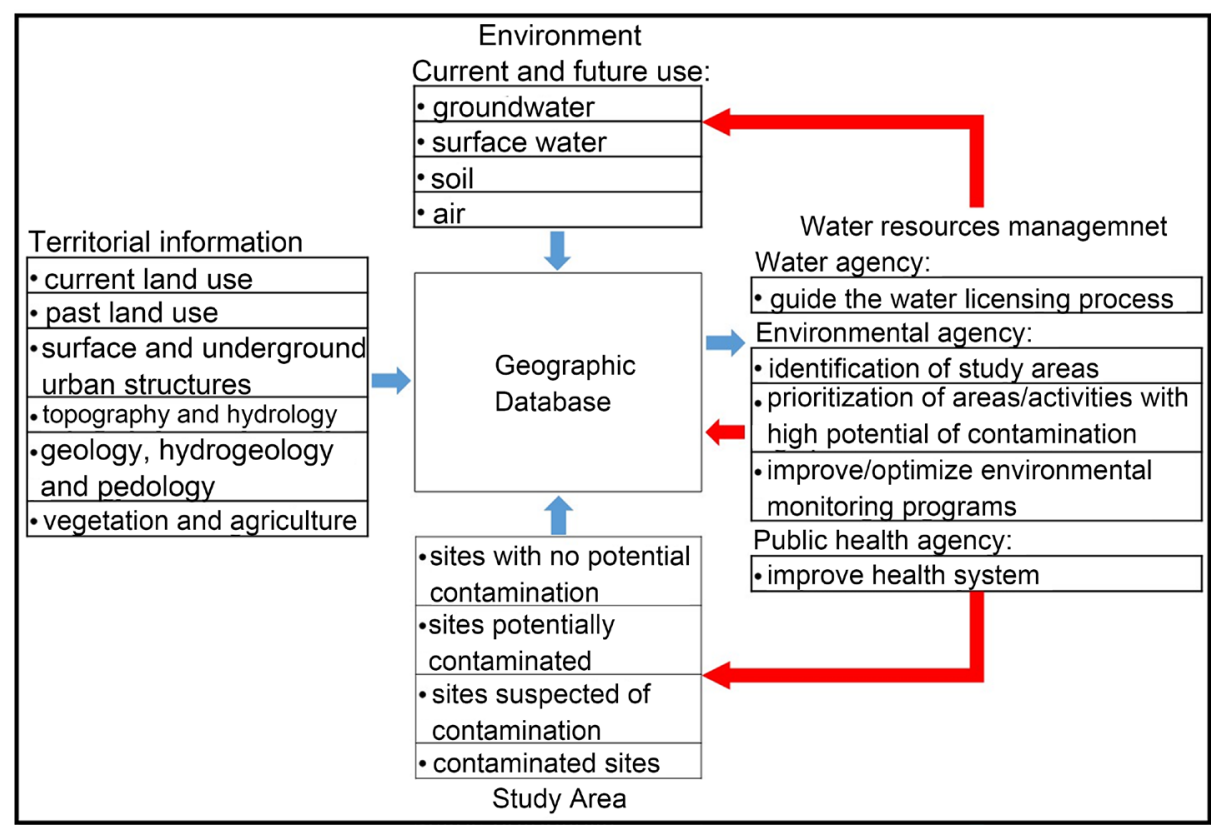

Figure 11. Application of the GDB for the management of water resources by the public agencies. 


\section{Acknowledgements}

We thank the environmental agency of Sao Paulo state, CETESB that facilitated the access to the data presented in reports of contaminated sites. We also thank FINEP (process 0110080800) for the project funding and FAPESP for providing scholarship (process 2012/11691-1). We also thank Professor Jun Shinohara for his support in database design and geoprocessing matters.

\section{References}

[1] Malina, G., Krupanek, J., Sievers, J., Grossmann, J., ter Meer, J. and Rijnaarts, H.H. (2006) Integrated Management Strategy for Complex Groundwater Contamination at a Megasite Scale. In: Twardowska, I., Allen, H.E., Häggblom, M.M. and Stefaniak, S., Eds., Soil and Water Pollution Monitoring, Protection and Remediation, Springer, Dordrecht, 567-577. https://doi.org/10.1007/978-1-4020-4728-2_37

[2] Schädler, S., Morio, M., Bartke, S. and Finkel, M. (2012) Integrated Planning and Spatial Evaluation of Megasite Remediation and Reuse Options. Journal of Contaminant Hydrology, 127, 88-100. https://doi.org/10.1016/j.jconhyd.2011.03.003

[3] CLARINET (2002) Review of Decision Support Tools for Contaminated Land Management: An Overview. http://www.commonforum.eu/publications_clarinet.asp

[4] Bardos, P. (2003) Sharing Experience in the Management of Megasites: Towards a Sustainable Approach in Land Management of Industrially Contaminated Sites. Report of the NICOLE Workshop, 29-31. http://www.nicole.org/uploadedfiles/NICOLE-Lille-October2003.pdf

[5] Carlon, C., Pizzol, L., Critto, A. and Marcomini, A. (2008) A Spatial Risk Assessment Methodology to Support Remediation of Contaminated Land. Environment International, 34, 397-411. https://doi.org/10.1016/j.envint.2007.09.009

[6] Schädler, S., Morio, M., Finkel, M. and Trefry, M.G. (2008) Land-Use Related Cost Estimates for Contaminated Site Development: Consequences of Uncertainty for Planning and Investment Decisions. Proceedings Groundwater Quality 2007 Conference, Fremantle, 2-7 December 2007, 539-546.

[7] Jamin, P., Dollé, F., Chisala, B., Orban, P., Popescu, I.C., Herivaux, C., Dassargues, A. and Brouyère, S. (2012) A Regional Flux-Based Risk Assessment Approach for Multiple Contaminated Sites on Groundwater Bodies. Journal of Contaminant Hydrology, 127, 65-75. https://doi.org/10.1016/j.jconhyd.2011.07.001

[8] Vega, A., Argus, R., Stockton, T., Black, P., Black, K. and Stiber, N. (2009) SMARTe: An MCDA Approach to Revitalize Communities and Restore the Environment. In: Marcomini, A., Suter, G.W. II and Critto, A., Eds., Decision Support Systems for Risk-Based Management of Contaminated Sites, Springer, New York, 1-26. https://doi.org/10.1007/978-0-387-09722-0_9

[9] Sullivan, T., Yatsalo, B., Grebenkov, A. and Linkov, I. (2009) Decision Evaluation for Complex Risk Network Systems (DECERNS) Software Tool. In: Marcomini, A., Suter, G.W. II and Critto, A., Eds., Decision Support Systems for Risk-Based Management of Contaminated Sites, Springer, New York, 1-18.

https://doi.org/10.1007/978-0-387-09722-0_12

[10] Ascough, J.C., Maier, H.R., Ravalico, J.K. and Strudley, M.W. (2008) Future Research Challenges for Incorporation of Uncertainty in Environmental and Ecological Decision-Making. Ecological Modelling, 219, 383-399. https://doi.org/10.1016/j.ecolmodel.2008.07.015

[11] Malczewski, J. (2006) GIS-Based Multicriteria Decision Analysis: A Survey of the Literature. International Journal of Geographical Information Science, 20, 703-726. 
https://doi.org/10.1080/13658810600661508

[12] Morio, M., Finkel, M., Schädler, S., Hartmuth, G., Rügner, H. and Trefry, M.G. (2008) Improving Mega-Site Revitalisation Strategies by Trading off Benefits from Future Land Use and Clean-Up Costs. Proceedings Groundwater Quality 2007 Conference, Fremantle, 2-7 December 2007, 555-562.

[13] SAO PAULO (2009) Projeto Jurubatuba: Restrição e controle de uso de água subterrânea. Secretaria de Estado de Saneamento e Recursos Hídricos, Departamento de Águas e Energia Elétrica; Secretaria de Estado do Meio Ambiente, Instituto Geológico. DAEE/IG, Sao Paulo, 109.

[14] CETESB (2015) Áreas Contaminadas Críticas. http://www.cetesb.sp.gov.br/

[15] L'Apiccirella, E.S. (2009) Contaminação e Áreas de Restrição de Uso de Água Subterrânea no Entorno do Canal Jurubatuba em Sao Paulo-SP. MSc. Thesis, University of Sao Paulo, Sao Paulo.

[16] Hirata, R.C. and Ferreira, L.M. (2008) Os aqüíferos da Bacia Hidrográfica do Alto Tietê: Disponibilidade hídrica e vulnerabilidade à poluição. Brazilian Journal of Geology, 31, 43-50.

[17] CBH-AT-COMITÊ DA BACIA HIDROGRÁFICA DO ALTO TIETÊ (2011) Áreas de restrição e controle para a captação e uso das águas subterrâneas no município de Sao Paulo, na região de Jurubatuba. Sao Paulo.

[18] Strassberg, G., Jones, N.L. and Maidment, D.R. (2011) Arc Hydro Groundwater. Esri Press, Redlands, California.

[19] ESRI (2013) Knowledge Base-Technical Articles: Data Models. http://downloads2.esri.com/support/TechArticles/Groundwater_Data_Model.pdf

[20] Jacob, A.M., Castro, G. and Miyashiro, N.J. (2012) Aplicação de método geoelétrico para caracterização geológica estratigráfica e estrutural. Thesis, SENAC, Sao Paulo.

[21] Pereira, E.V. and Sartini, R.P. (2007) Gerenciamento de Áreas Contaminadas na Região do Jurubatuba. Thesis, SENAC, Sao Paulo.

[22] CETESB (2014) Relação de Áreas Contaminadas e Reabilitadas. http://www.cetesb.sp.gov.br/areas-contaminadas/rela\%E7\%F5es-de-\%E1\%A1reas-c ontaminadas/4-rac

[23] US Soil Survey Staff (1993) Soil Survey Manual. United States Department of Agriculture, Washington DC.

[24] Bertolo, R.A. (1996) Relações entre rios e o aqüífero sedimentar da Bacia de Sao Paulo em área de exploração intensiva de água subterrânea. PhD Dissertation, University of Sao Paulo, Sao Paulo.

[25] Rebouças, A. (1992) Condições de uso e proteção das águas subterrâneas. Proceedings Problemas Geológicos e Geotécnicos na RMSP, ABAS/ABGE/SBG-SP, Sao Paulo, 77-87.

[26] Fernandes, A.J., Fiume, B., Bertolo, R. and Hirata, R.C.A. (2016) Modelo geométrico de fraturas e análise da tectônica rúptil aplicados ao estudo do fluxo do aquífero cristalino, Sao Paulo (SP). Geologia USP, 16, 71-88. https://doi.org/10.11606/issn.2316-9095.v16i3p71-88

[27] Pankow, J.F. and Cherry, J.A. (1996) Dense Chlorinated Solvents and Other DNAPLs in Groundwater: History, Behavior, and Remediation. Waterloo Press, Ontario. 
Submit or recommend next manuscript to SCIRP and we will provide best service for you:

Accepting pre-submission inquiries through Email, Facebook, LinkedIn, Twitter, etc. A wide selection of journals (inclusive of 9 subjects, more than 200 journals)

Providing 24-hour high-quality service

User-friendly online submission system

Fair and swift peer-review system

Efficient typesetting and proofreading procedure

Display of the result of downloads and visits, as well as the number of cited articles Maximum dissemination of your research work

Submit your manuscript at: http://papersubmission.scirp.org/

Or contact jwarp@scirp.org 